\title{
Broadscale phylogeographic structure of five freshwater fishes across the Australian Monsoonal Tropics
}

\author{
Joel A. Huey ${ }^{1,4}$, Benjamin D. Cook $^{2,5}$, Peter J. Unmack ${ }^{3,6}$, and Jane M. Hughes ${ }^{1,7}$ \\ ${ }^{1}$ Australian Rivers Institute and National Environmental Research Program Northern Australia Hub, Griffith University, Nathan, \\ Queensland 4111, Australia \\ ${ }^{2}$ Australian Rivers Institute and Tropical Rivers and Coastal Knowledge Commonwealth Environmental Research Facility, Griffith \\ University, Nathan, Queensland 4111, Australia \\ ${ }^{3}$ National Evolutionary Synthesis Center, 2024 West Main Street, Suite A200, Durham, North Carolina 27705-4667 USA
}

\begin{abstract}
The Australian Monsoonal Tropics (AMT) is a unique location for the study of phylogeography and intraspecific genetic variation in freshwater fish. We assessed the phylogeographic structure of 5 species from 2 genera across the region. The species included 3 neosilurids (Plotosidae, Neosilurus hyrtlii, Neosilurus ater, and Neosilurus pseudospinosus) and 2 members of the genus Oxyeleotris (Eleotridae, O. selheimi and O. lineolata). We used mitochondrial deoxyribonucleic acid (mtDNA) and phylogenetic analyses to explore the phylogeographic histories of these species. Overall, phylogeographic patterns were inconsistent. Some species were highly structured, and phylogeographic breaks were detected (e.g., N. hyrtlii, N. pseudospinosus, and O. selheimi), but other species showed no obvious divergences across the AMT ( $N$. ater and O. lineolata). All species sampled in the Gulf of Carpentaria had shallow phylogenies, consistent with the expectation that historically, Lake Carpentaria would have provided connectivity through this region. All species also showed evidence of recent connectivity across drainage divides on the eastern and western coasts of the Cape York Peninsula. Some species in the Kimberley region were highly structured, consistent with expectation that these ancient and geologically stable catchments would promote divergence in allopatry. Conservation efforts should now be directed toward ensuring that the intraspecific biodiversity identified in our study and others are protected in the future.

Key words: Neosilurus hyrtlii, Neosilurus ater, Neosilurus pseudospinosus, Oxyeleotris selheimi, Oxyeleotris lineolata, comparative phylogeography
\end{abstract}

The Australian continent has a depauperate freshwater fish fauna, thought to originate from its arid climate and historical isolation from other land masses (Unmack 2001, 2013, Allen et al. 2002). However, the Australian fish fauna is poorly understood, and much biodiversity at the species and intraspecific level has not yet been documented. For example, in a recent phylogenetic reassessment of the rainbowfishes (Melanotaeniidae) in Australia and New Guinea, 15 to 20 new or unrecognized species were identified (Unmack et al. 2013). Within species, researchers are finding genetically distinct clades (e.g., Cook et al. 2014), a situation that has led to reconsideration of the formation and patterns of biodiversity on the continent.

In particular, the biodiversity and biogeography of northern Australia is poorly understood relative to the southern part of the continent (Bowman et al. 2010). This region is dominated by the Australian summer monsoon and often is described as the Australian Monsoon Tropics (AMT; Bowman et al. 2010). Although it is sparsely populated by humans, the AMT is seen as a region of future economic development (Bowman et al. 2010). The abundant supply of freshwater during summer is an attractive asset on an otherwise dry continent, and these riverine resources will require management as the region is developed. New insights into freshwater biodiversity across northern Australia will enable approaches to river management that account for unique biodiversity features, such as areas with high endemism or taxonomic richness. For example, ongoing conservation planning is being undertaken to identify regions for conserving aquatic biodiversity in northern Aus-

E-mail addresses: ${ }^{4}$ j.huey@griffith.edu.au; ${ }^{5}$ Present address: frc environmental, P.O. Box 2363, Wellington Point, Queensland 4160, Australia, bencook@frcenv.com.au; ${ }^{6}$ Present address: Institute for Applied Ecology, University of Canberra, Canberra, Australian Capital Territory 2601, Australia, peter.pub@unmack.net; 7jane.hughes@griffith.edu.au

DOI: 10.1086/674984. Received 03 March 2013; Accepted 10 September 2013; Published online 26 December 2013. 
tralia (Kennard 2010, Hermoso et al. 2011, 2012a, b, Linke et al. 2012). Enhanced knowledge of basic biodiversity of the freshwater fauna of this region will augment these conservation efforts.

Comparative phylogeography is a powerful tool for investigating biodiversity in this region. If we can identify congruent patterns of intraspecific divergence and link these to landscape features that may have shaped these patterns, we might be able to make broad generalizations about biodiversity across the entire region. For example, in the rainforests of northeastern Australia, snails and insects are strong predictors (or surrogates) for climatedriven vicariance in vertebrates (Moritz et al. 2001). However, authors of many comparative phylogeographic studies have identified incongruent patterns of intraspecific divergence (e.g., Michaux et al. 2004), making generalization difficult. When incongruence is observed, possible ecological differences between species that may explain such inconsistencies must be identified (Unmack 2013). For example, differences in life history, such as migratory behavior (e.g., Schmidt et al. 2014), are likely to alter phylogeographic patterns dramatically by providing connectivity for some species and not others.

The main feature that has shaped the phylogeographic history of freshwater species in the AMT is the Gulf of Carpentaria (catchments 20-32; Fig. 1A). Historically, the gulf has alternated intermittently between being a brackish gulf and a freshwater lake (Lake of Carpentaria), which was most recently inundated by saltwater $\sim 10,000$ y ago (Fig. 1A; Torgersen et al. 1988, Chivas et al. 2001, Voris 2001). This large freshwater lake and associated drainages may have connected populations of many freshwater taxa from the eastern Top End to the eastern Gulf and New Guinea (Fig. 1B). Many investigators have studied genetic variation in species that would have been connected by Lake Carpentaria and repeatedly have found shallow phylogenies and a historical relationship with New Guinea (de Bruyn et al. 2004, Baker et al. 2008, Masci et al. 2008, Huey et al. 2010, Cook et al. 2012). This large homogenizing feature is bookended by 2 other regions. The east coast of Australia is separated from the Gulf of Carpentaria by Torres Strait, a currently 10-m-deep passage between Cape York and New Guinea, which has intermittently formed a land bridge separating the east coast and western gulf during sea-level fluctuations (Chivas et al. 2001, Voris 2001). Torres Strait acts as a barrier to dispersal for a freshwater prawn (de Bruyn et al. 2004). Headwaters along the Great Dividing Range, which separates eastern and western flowing catchments on Cape York Peninsula, are in close proximity, and low-relief drainage boundaries and high rainfall may have provided occasional opportunities for dispersal. As a result, the fish fauna is similar on both sides of Cape York (Unmack 2013).
Phylogeographic breaks have been found on the western side of the Gulf of Carpentaria basin and Top End (catchments 19-20; Fig. 1A) for freshwater shrimps, crayfishes, and fishes (de Bruyn et al. 2004, Baker et al. 2008, Huey et al. 2011). For shrimps, a shallow break (0.33\%, 602-basepair [bp] fragment of cytochrome $c$ oxidase subunit 1 [CO1] mitochondrial deoxyribonucleic acid [mtDNA]) was detected between the Roper and Daly catchments (catchment 21 and 13; Fig. 1A), whereas a deeper break (3.9\%, 523-bp fragment of CO1 mtDNA) was found between the Roper and McArthur catchments for crayfish (catchments 21 and 22; Fig 1A). For fish, a phylogenetic break (1.3\%, 396-bp fragment of control region mtDNA) was found between subcatchments of the Nicholson catchment (catchment 24; Fig. 1A). These breaks are often attributed to the historical positioning of drainages, whereby catchments in the Top End region independently flowed to either the Arafura Sea or the discharge from Lake Carpentaria (Voris 2001). The exact location of these breaks varies from species to species, possibly because of more recent dispersal across catchment boundaries.

Further west, in the Cambridge Gulf (catchments 9 to 14; Fig. 1A), is a region of low topography where catchments would have merged during periods of lower sea level. Biogeographic analyses suggest recent connectivity among catchments during periods of low sea level, and flooding may connect catchments intermittently over contemporary time frames (Unmack 2001). This situation contrasts with Kimberley (catchments 1-8; Fig. 1A), which is characterized by ancient, geologically stable catchments (Ollier et al. 1988, Gale 2006). Therefore, for the species that inhabit this region, large divergences are often detected among close catchments (Phillips et al. 2009, Cook et al. 2011b, Young et al. 2011). For example, Cook et al. (2011b) found many divergent lineages of freshwater caridean shrimp in the Prince Regent, King Edward, and Drysdale catchments (catchments 5, 6, 7; Fig. 1A).

To date, few phylogeographic studies of freshwater species in this region have focused on genetic patterns across the entire region for a single species. One exception is a freshwater fish, Leiopotherapon unicolor, for which none of the abovementioned intraspecific divergences were observed (Bostock et al. 2006). This result suggests that for widespread species, dispersal ability may be the most important factor shaping phylogeographic patterns. Leiopotherapon unicolor is renowned for its ability to colonize new habitats (Unmack 2013). However, Bostock et al. (2006) were attempting to identify cryptic species rather than describe intraspecific variation. Therefore, they used a slowly evolving mtDNA gene (16S ribosomal ribonucleic acid), so they may have missed important intraspecific variation. We investigated 5 species to provide more information about the phylogeographic history of widespread species in the AMT. Four species have a broad distribution (Neosilurus 


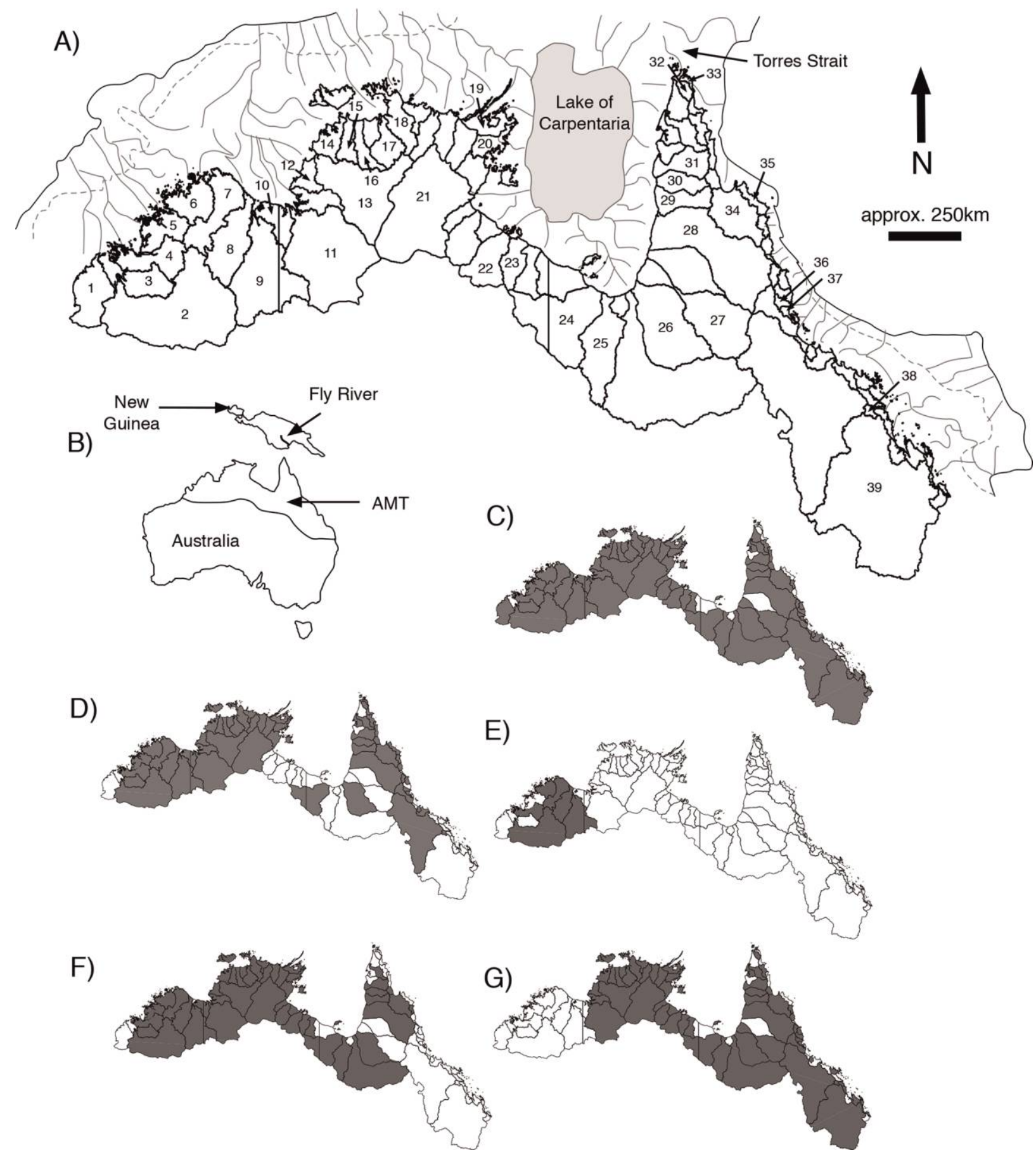

Figure 1. A.-Map of the Australian Monsoon Tropics (AMT) showing major catchment boundaries on the Australian continent, with the paleodrainages in grey. Paleodrainages were adapted from Unmack (2001). The outer boundary represents the $500 \mathrm{~m}$ below sea level (bsl) mark, with $100 \mathrm{~m}$ bsl marked with a dashed line. Catchments are: 1) Cape Leveque Coast, 2) Fitzroy (Western Australia), 3) Lennard, 4) Isdell, 5) Prince Regent, 6) King Edward, 7) Drysdale, 8) Pentecost, 9) Ord, 10) Keep, 11) Victoria, 12) Moyle, 13) Daly, 14) Finniss, 15) Adelaide, 16) Mary, 17) South Alligator, 18) East Alligator, 19) Buckingham, 20) Koolatong, 21) Roper, 22) McArthur, 23) Robinson, 24) Nicholson, 25) Leichhardt, 26) Norman, 27) Gilbert, 28) Mitchell, 29) Coleman, 30) Holroyd, 31) Archer, 32) Jardine, 33) Jacky Jacky, 34) Normanby, 35) Jeannie, 36) Tully, 37) Herbert, 38) Pioneer, 39) Fitzroy (Queensland). B.-Australian and New Guinea land masses, showing the AMT and Fly River. C.-Species distribution for Neosilurus hyrtlii. D.-Species distribution for Neosilurus ater. E.-Species distribution for Neosilurus pseudospinosus. F.-Species distribution for Oxyeleotris selheimi. G.-Species distribution for O. lineolata. Species distributions were taken from Allen et al. (2002) and Pusey et al. (2004). 
hyrtlii, Neosilurus ater, Oxyeleotris selheimi, Oxyeleotris lineolata), and one has a narrow distribution (Neosilurus pseudospinosus). We chose multiple species from within 2 genera because similar ecological niches, behaviors, and physiological tolerances could possibly lead to similar phylogeographic patterns among species within a genus.

Our goal was to describe the broad-scale patterns of genetic structure in these species and to understand the historical role of landscape features and species biology in shaping genetic variation across the AMT, in particular on widely distributed species. From this data set, we described general comparative phylogeographic patterns and proposed hypotheses for future research. Based on the broad landscape features that are likely to shape phylogeographic structure in the AMT, we expected to identify the following patterns: 1) Populations distributed within the Gulf of Carpentaria region (catchments 20-32; Fig. 1A) will have shallow phylogenies, indicative of the homogenizing effect of Lake Carpentaria in the recent past. This shared history across Lake Carpentaria will extend to populations in southern New Guinea. 2) Populations distributed throughout catchments flowing east and west across the Cape York Peninsula (catchments 28-35; Fig. 1A) will have a recent shared history because of possible recent dispersal events across the Great Dividing Range. 3) Phylogeographic breaks will be observed west of the Gulf of Carpentaria (in the region surrounding catchments 19 and 20; Fig. 1A). 4) Populations will show low genetic structure through the Cambridge Gulf (catchments 9-14; Fig. 1A), consistent with recent hydrological connections and ongoing flooding that might connect populations contemporaneously. 5) Many distinct lineages will be detected in Kimberley (catchments 1-8; Fig. 1A), corresponding to ancient, more isolated drainages.

\section{METHODS}

\section{Study species}

Neosilurus hyrtlii is one of the most widely distributed and abundant species on the Australian continent (Fig. 1C) and has a distribution similar to that of L. unicolor. Neosilurus hyrtlii exists across many drainage basins from southeastern Queensland across the endorheic desert catchments and the AMT, but phylogeographic studies have only found small divergences across major basin divides (Huey et al. 2006, 2008). These studies were conducted in the aridzone catchments of central Australia and in the Gulf of Carpentaria. No published studies have been carried out across the AMT. Neosilurus hyrtlii appears to have traversed catchment boundaries more recently than other species in central Australia and the Gulf of Carpentaria, a pattern suggesting a strong dispersal ability (Hughes et al. 2009).

Neosilurus ater has a much smaller distribution than N. hyrtlii (Fig. 1D). However, unlike N. hyrtlii, N. ater also is found in southern New Guinea. Specific distribution data are poor for $N$. ater, but it is thought to be distributed continuously across the AMT (Pusey et al. 2004). On the east coast, $N$. ater is found as far south as the Pioneer River (catchment 38; Fig. 1A). Neosilurus pseudospinosus is an uncommon and geographically constrained species that exists in a number of catchments in the Kimberley and western Northern Territory (Fig. 1E). Oxyeleotris lineolatus and O. selheimi are ecologically similar and have largely sympatric ranges (Fig. 1F, G; Pusey et al. 2004). Both species are widely distributed across the AMT and occur in southern New Guinea. Regional phylogeographic studies have not been undertaken for $N$. ater, N. pseudospinosus, O. lineolatus, or O. selheimi.

\section{Sampling and genetic analyses}

Individuals of all 5 species were sampled from across their range in the AMT and from New Guinea (3 species) (Fig. 2A, B). Our goal was to describe broad-scale patterns of phylogeographic structure, especially among the regions described above. We placed emphasis on sampling as many catchments as possible rather than on collecting many samples from within catchments. For many catchments, only a single individual was collected (Table 1). However, we think this sampling strategy is adequate to make generalizations about phylogeographic structure in these species on a broad scale.

We caught fishes with seine nets and backpack electrofishing units. Upon capture, we identified fishes, preserved a fin clip in ethanol, and returned the specimen to the water. Genomic DNA was extracted by the methods of Doyle and Doyle (1987). We amplified a fragment of the ATPase 6 and 8 mtDNA genes using the same primers, polymerase chain reaction (PCR) conditions and sequencing protocols described by Cook and Hughes (2010).

\section{Statistical analyses}

We aligned sequences with SEQUENCHER (version 4.1.2; Gene Codes Corporation, Ann Arbor, Michigan) and trimmed them to a single length for analysis. For the 3 Neosilurus species, we successfully sequenced and aligned 694 bp of mtDNA. For the 2 Oxyeleotris species, we successfully sequenced and aligned $716 \mathrm{bp}$ of mtDNA.

We visualized the haplotype data with $95 \%$ parsimony networks, calculated with TCS (version 1.21; Clement et al. 2000). Within some species, the evolutionary relationships between some groups of haplotypes could not be resolved using networks. For ease of communication, we refer to these disconnected groups as haplogroups. To give evolutionary context to these haplogroups, we ran maximum likelihood (ML) analyses with RAxML-HPC2 on XSEDE (version 7.6.3; Stamatakis 2006) using the CIPRES Science Gateway (Miller et al. 2010). The best tree was found under the General Time Reversible + Gamma (GTR+G) 


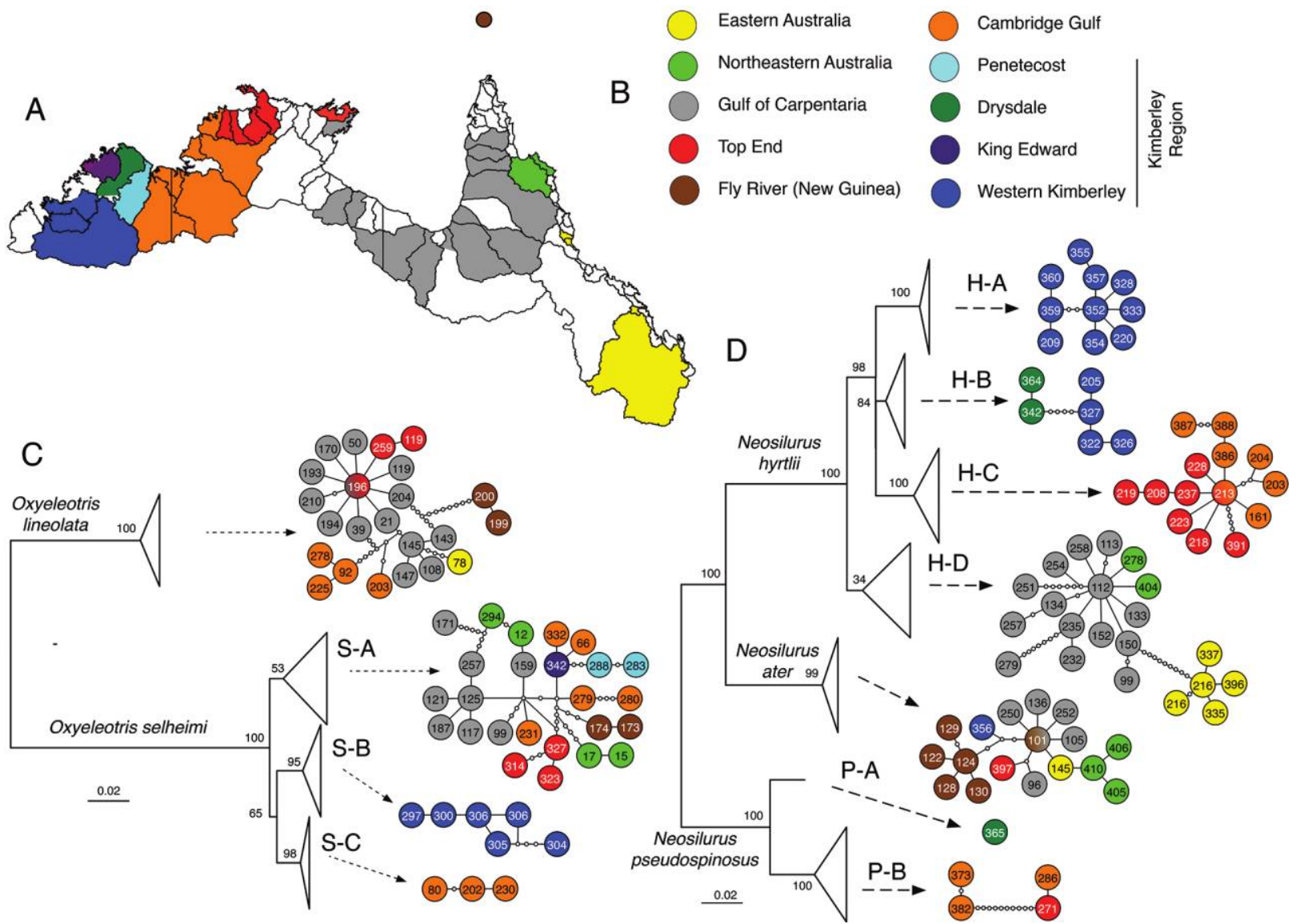

Figure 2. Graphical synthesis of mitochondrial deoxyribonucleic acid (mtDNA) data for all species. A.-Map of Australian Monsoonal Tropics (AMT) drainages sampled in our study, with major regions marked with a color, corresponding to the key. Kimberley is divided into separate catchments to show better the spatial distribution of genetic variation in this region. B.-Color key. C.-Maximum likelihood phylogeny for the Oxyeleotris genus, with separate haplogroups marked and collapsed. D.-Maximum likelihood phylogeny for the Neosilurus genus. Values on the nodes represent bootstrap support out of 100. Networks are color coded to correspond with the key. See Table S1 for haplotype numbers. See Table 2 for genetic distances among and within haplogroups and regions. GenBank accession numbers for haplotypes are KF413445-KF413576.

model, and bootstrap support was estimated using 1000 replicates (Stamatakis et al. 2008). We ran a ML analysis on each genus to allow direct comparisons of the divergences among haplogroups.

Average maximum composite likelihood pairwise genetic divergences among and within observed haplogroups and regions were calculated using MEGA 5.1 (Tamura et al. 2011).

\section{RESULTS}

\section{Broad-scale}

Oxyeleotris selheimi consisted of 34 haplotypes grouped into 3 haplogroups (Fig. 2C, Tables 1, S1) sequenced from 124 individuals. Samples were taken from 22 catchments across the entire distribution of $O$. selheimi and included samples from New Guinea (Table 1). Haplogroups S-B and S-C were strongly supported (95/100 and 98/100 re- spectively), whereas S-A was weakly supported (53/100). These haplogroups were similarly divergent (2.58-2.76\%; Table 2) and the evolutionary relationships among haplogroups were poorly resolved. The 3 haplogroups had overlapping distributions. Haplogroup S-A was distributed almost throughout the range of the species, including New Guinea. Haplogroup S-C was restricted to Cambridge Gulf, and was sympatric with haplogroup S-A in the Daly catchment (catchment 13; Fig. 1A). Haplogroup S-B was allopatric relative to the other samples and was found only in western Kimberly.

Across 137 sequenced $O$. lineolata individuals we found only 1 strongly resolved haplogroup comprising 23 haplotypes. Samples came from 18 catchments throughout its recognized range, including the Fly River in New Guinea (Fig. 2C, Tables 1, S1).

Neosilurus hyrtlii consisted of 51 haplotypes grouped into 4 haplogroups (Fig. 2F) sequenced from 129 individ- 
Table 1. Catchments sampled for this study, showing sample sizes for each species. Numbers in parentheses refer to catchment numbers in Fig. 1A. ${ }^{1}=$ Murray River (between the Herbert [37] and Tully [36] catchments), ${ }^{2}=$ Muck River (between the Normanby [34] and Jeannie [35] catchments), ${ }^{3}=$ Edward River (between the Holroyd [30] and Coleman [29] catchments), ${ }^{4}=$ Wearyan River (between the Robinson [23] and McArthur [22] catchments), ${ }^{5}=$ Cato (between the Buckingham [19] and Koolatong [20] catchments). ${ }^{6}=$ Reynolds River (between the Finnis [14] and Daly [13] catchments), ${ }^{7}=$ Durack River (between the Drysdale [7] and Pentecost [8] catchments), ${ }^{8}$ Robinson River (between the Isdell [4] and Lennard [3] catchments), ${ }^{9}=$ May River (between the Lennard [3] and Fitzroy WA [2] catchments), QLD = Queensland, WA = Western Australia.

\begin{tabular}{|c|c|c|c|c|c|c|}
\hline Region & Catchment & $\begin{array}{l}\text { Neosilurus } \\
\text { hyrtlii }\end{array}$ & $\begin{array}{l}\text { Neosilurus } \\
\text { ater }\end{array}$ & $\begin{array}{c}\text { Neosilurus } \\
\text { pseudospinosus }\end{array}$ & $\begin{array}{l}\text { Oxyeleotris } \\
\text { selheimi }\end{array}$ & $\begin{array}{l}\text { Oxyeleotris } \\
\text { lineolata }\end{array}$ \\
\hline New Guinea & Fly River & & 16 & & 5 & 2 \\
\hline \multirow[t]{5}{*}{ Eastern Australia } & Fitzroy (QLD) (39) & 2 & & & & 2 \\
\hline & Pioneer (38) & 3 & & & & \\
\hline & Herbert (37) & 5 & & & & \\
\hline & Murray $^{1}$ & 6 & & & & \\
\hline & Tully (36) & 2 & 6 & & & \\
\hline \multirow[t]{2}{*}{ Northeastern Australia } & Muck $^{2}$ & 1 & 6 & & & \\
\hline & Normanby (34) & 1 & & & 10 & \\
\hline \multirow[t]{13}{*}{ Gulf of Carpentaria } & Archer (31) & 2 & & & & \\
\hline & Holroyd (30) & 3 & 1 & & 8 & 8 \\
\hline & Edward $^{3}$ & & & & 5 & 3 \\
\hline & Coleman (29) & 9 & 4 & & 6 & 3 \\
\hline & Mitchell (28) & 10 & 15 & & 3 & 42 \\
\hline & Gilbert (27) & & & & 5 & \\
\hline & Norman (26) & 4 & & & 8 & 12 \\
\hline & Leichhardt (25) & 2 & & & & 5 \\
\hline & Nicholson (24) & 2 & & & & 1 \\
\hline & Robinson (23) & & 4 & & 1 & 8 \\
\hline & Wearyan $^{4}$ & & 3 & & 9 & \\
\hline & McArthur (22) & & 1 & & & 11 \\
\hline & Koolatong (20) & & & & 3 & 1 \\
\hline \multirow[t]{5}{*}{ Top End } & Cato $^{5}$ & & & 1 & & \\
\hline & East Alligator (18) & & 1 & & 7 & \\
\hline & South Alligator (17) & 1 & & & 5 & 1 \\
\hline & Mary (16) & 1 & & & & 2 \\
\hline & Adelaide (15) & 12 & & & & 2 \\
\hline \multirow[t]{7}{*}{ Cambridge Gulf } & Finniss (14) & 2 & & & & 1 \\
\hline & Reynolds $^{6}$ & 1 & & & & \\
\hline & Daly (13) & 4 & & 4 & 8 & 32 \\
\hline & Moyle (12) & 1 & & & 1 & \\
\hline & Victoria (11) & 2 & & 2 & 2 & \\
\hline & Keep (10) & 1 & & & 1 & \\
\hline & Ord (9) & & & 14 & 13 & 1 \\
\hline \multirow[t]{7}{*}{ Kimberley } & Durack $^{7}$ & & & & 3 & \\
\hline & Drysdale (7) & 4 & & 1 & & \\
\hline & King Edward (6) & & & & 1 & \\
\hline & Robinson $^{8}$ & & & & 7 & \\
\hline & Isdell (4) & 10 & & & & \\
\hline & May $^{9}$ & 2 & & & & \\
\hline & Fitzroy (WA) (2) & 36 & 3 & & 13 & \\
\hline
\end{tabular}


uals (Tables 1, S1). Samples were taken from 27 catchments, from the full distribution of the species in the AMT and included samples from the east coast of Australia. A subset of the haplogroups ( $\mathrm{H}-\mathrm{A}, \mathrm{H}-\mathrm{B}$, and $\mathrm{H}-\mathrm{C})$ formed a strongly supported polytomy, $\sim 3.2$ to $\sim 4.3 \%$ divergent from each other (Table 2). These 3 haplogroups were restricted to the catchments west of the Gulf of Carpentaria. Haplogroups H-A and H-B were restricted to Kimberly, whereas H-C was restricted to Cambridge Gulf and Top End. Haplogroup H-D was only weakly supported (bootstrap support $=34 / 100$ ) and was found across the Gulf of Carpentaria and along eastern Australia. Within Haplogroup H-D, 2 distinct groups were evident, one restricted to the Gulf of Carpentaria and northeastern Australia and the other found further south on the east coast. These groups were $1.8 \%$ divergent.

Neosilurus ater consisted of a single haplogroup comprising 17 haplotypes sequenced from 60 individuals (Fig. 2D, Tables 1, S1). Samples were taken from 11 catchments from the east coast to the Kimberley region, including samples from the Fly River in New Guinea.

Neosilurus pseudospinosus consisted of 5 haplotypes grouped into 2 haplogroups sequenced from 22 individuals (Fig. 2D, Tables 1, S1). These were sampled from Kimberley. One sample was taken from the Cato catchment in Top End (between catchments 19 and 20; Fig. 1A), from outside its recognized range. Haplogroup P-A was found in the Drysdale catchment (catchment 7; Fig. 1A) and was $1.22 \%$ divergent from haplogroup P-B (Table 2). Haplogroup $\mathrm{P}-\mathrm{B}$ comprised 2 distinct groups that were $0.48 \%$ divergent.

\section{Gulf of Carpentaria, New Guinea, Northeastern and Eastern Australia}

Within the Gulf of Carpentaria (gray region in Fig. 2A), shallow phylogenies were detected for O. selheimi, O. lineolata, N. hyrtlii, and $N$. ater. Most of the haplotypes for these species in this region were closely related (withinregion pairwise sequence divergence $=0.13-0.41 \%$; Table 2) and formed star-shaped phylogenies. The exceptions were haplotype 171 for O. selheimi from haplogroup S-A and $N$. hyrtlii haplotypes 251 and 279 in haplogroup H-D. For $O$. selheimi, the divergent haplotype was sampled in the Edward catchment (between catchments 30 and 31; Fig. 1A, Table S1), where haplotype 159 was sampled. Both of the highly divergent haplotypes for $N$. hyrtlii were sampled from the Coleman catchment (catchment 29; Fig. 1A), where haplotypes 99, 113, 112, and 235 were sampled.

Evolutionary relationships for the 3 species that were sampled from the Fly River differed between the AMT and New Guinea. For O. lineolata, the Fly River samples were highly divergent, but most closely related to the Gulf of Carpentaria samples $(\sim 1.8 \%$ divergent from all Gulf of Carpentaria samples; Fig. 2C, Table 2). For O. selheimi, some divergence was found $(0.98 \%$ divergent from the
Gulf of Carpentaria samples; Fig. 2C, Table 2), but the samples were most closely related to Cambridge Gulf samples. Homoplasy and many unsampled haplotypes in the haplogroup S-A network suggest that the evolutionary relationships among regions are not clear. For $N$. ater, haplotype 101 was shared between the Gulf of Carpentaria and New Guinea, but many unique haplotypes were found in each region ( $0.073 \%$ mean divergence; Table 2$)$.

Pairwise divergences between the Gulf of Carpentaria and northeastern Australia were low, but no shared haplotypes were found for the 3 species for which these samples were available (between the Gulf of Carpentaria samples and the northeastern Australia samples: O. selheimi, 0.63\%; N. hyrtlii, $0.36 \%$; N. ater, $0.47 \%$; Table 2). For O. selheimi, 2 distinct groups of haplotypes were found (haplotypes 294 and 12, 17 and 15; Fig. 2C), which were all sampled from the Normanby catchment (catchment 34 in Fig. 1A, Table S1).

Samples of 3 species (O. lineolata, N. hyrtlii, and $N$. ater) were collected from catchments on the east coast of the continent that did not share catchment boundaries with the Gulf of Carpentaria (yellow catchments in Fig. 2A). For N. hyrtlii, the eastern Australian samples were highly divergent (1.8\% divergent; Table 2$)$. For $O$. lineolata and $N$. ater, they were much less divergent.

\section{Gulf of Carpentaria vs the Top End and Cambridge Gulf}

For O. selheimi, O. lineolata, and $N$. ater, only weak phylogeographic breaks were found between the Gulf of Carpentaria catchments and those catchments further to the west. For $O$. lineolata, the pairwise divergence was low, and a haplotype was shared between the Gulf of Carpentaria and the Top End (haplotype 196; Fig. 2C). For O. selheimi, no haplotypes were shared, and the divergence between the Gulf of Carpentaria samples and Top End and Cambridge Gulf samples was 1.02\% (Table 2). For $N$. ater, only a recent divergence was detected between the Gulf of Carpentaria and Top End samples (0.39\%; Table 2). In contrast, a unique haplogroup of $N$. hyrtlii that did not occur in Top End, Cambridge Gulf ( $\mathrm{H}-\mathrm{C})$, and Kimberly ( $\mathrm{H}-\mathrm{A}$ and $\mathrm{H}-\mathrm{B})$ was found in the Gulf of Carpentaria/East Coast region (H-D). Haplogroup $\mathrm{H}-\mathrm{D}$ was $4.82 \%$ divergent from haplogroup $\mathrm{H}-\mathrm{C}$ (Table 2).

\section{Cambridge Gulf}

Patterns within Cambridge Gulf were variable. For $N$. hyrtlii, haplotypes were closely related, with low average divergence (0.004; Table 2). In contrast, a highly divergent haplotype for $N$. pseudospinosus was found in the Daly catchment (haplotype 286; Fig. 2D, Table S1). For O. selheimi, a similar pattern was observed, with 2 distinct haplogroups in the Daly catchment (haplogroups S-A and S-C; Table S1). Within haplogroup S-A, Cam- 
Table 2. Within- and between-clade average maximum composite likelihood pairwise distances. The clades are based on those described in Fig. 2C, D. Haps = haplotypes.

\begin{tabular}{|c|c|c|c|}
\hline Comparison & Species & Comparison & $\begin{array}{l}\text { Average pairwise } \\
\text { genetic distance }\end{array}$ \\
\hline \multicolumn{4}{|l|}{ Between haplogroups and regions } \\
\hline \multicolumn{4}{|l|}{ Broadscale } \\
\hline \multirow[t]{10}{*}{ Between haplogroups } & Oxyeleotris selheimi & Haplogroup S-A vs S-B & 0.0276 \\
\hline & O. selheimi & Haplogroup S-A vs S-C & 0.0274 \\
\hline & O. selheimi & Haplogroup S-B vs S-C & 0.0258 \\
\hline & Neosilurus hyrtlii & Haplogroup H-A vs H-B & 0.0320 \\
\hline & N. hyrtlii & Haplogroup H-A vs H-C & 0.0434 \\
\hline & N. hyrtlii & Haplogroup H-A vs H-D & 0.0476 \\
\hline & N. hyrtlii & Haplogroup H-B vs H-C & 0.0319 \\
\hline & N. hyrtlii & Haplogroup H-B vs H-D & 0.0319 \\
\hline & N. hyrtlii & Haplogroup H-C vs H-D & 0.0482 \\
\hline & Neosilurus pseudospinosus & Haplogroup P-A vs P-B & 0.0122 \\
\hline \multicolumn{4}{|l|}{ Regional comparisons } \\
\hline Gulf of Carpentaria vs & Oxyeleotris lineolata & & 0.0182 \\
\hline \multirow[t]{2}{*}{ New Guinea } & O. selheimi (S-A) & & 0.0098 \\
\hline & Neosilurus ater & & 0.0073 \\
\hline Gulf of Carpentaria vs & O. selheimi (S-A) & All & 0.0063 \\
\hline \multirow[t]{4}{*}{ Northeastern Australia } & O. selheimi (S-A) & Gulf vs haps 294 and 12 & 0.0046 \\
\hline & O. selheimi (S-A) & Gulf vs haps 17 and 15 & 0.0131 \\
\hline & N. hyrtlii (H-D) & & 0.0036 \\
\hline & N. ater & & 0.0047 \\
\hline Northeastern Australia vs & N. hyrtlii (H-D) & & 0.0181 \\
\hline Eastern Australia & N. ater & & 0.0022 \\
\hline Gulf of Carpentaria vs Top & O. lineolata & & 0.0102 \\
\hline \multirow[t]{3}{*}{ End/Cambridge Gulf } & O. selheimi (S-A), not S-C & & 0.0067 \\
\hline & N. hyrtlii (H-D vs H-C) & & 0.0482 \\
\hline & N. ater & & 0.0039 \\
\hline \multicolumn{4}{|l|}{ Within haplogroups and regions } \\
\hline \multicolumn{4}{|l|}{ Broadscale } \\
\hline \multirow[t]{11}{*}{ Within haplogroups/species } & O. lineolata & Within species & 0.0057 \\
\hline & O. selheimi & Haplogroup S-A & 0.0065 \\
\hline & O. selheimi & Haplogroup S-B & 0.0020 \\
\hline & O. selheimi & Haplogroup S-C & 0.0028 \\
\hline & N. hyrtlii & Haplogroup H-A & 0.0029 \\
\hline & N. hyrtlii & Haplogroup H-B & 0.0039 \\
\hline & N. hyrtlii & Haplogroup H-C & 0.0038 \\
\hline & N. hyrtlii & Haplogroup H-D & 0.0103 \\
\hline & N. ater & Within species & 0.0047 \\
\hline & N. pseudospinosus & haplogroup P-A & 0.0000 \\
\hline & N. pseudospinosus & haplogroup P-B & 0.0011 \\
\hline \multicolumn{4}{|l|}{ Within regions } \\
\hline \multirow[t]{3}{*}{ East Coast } & O. lineolata & & 0.0000 \\
\hline & N. hyrtlii & & 0.0009 \\
\hline & N. ater & & 0.0000 \\
\hline
\end{tabular}


Table 2 (Continued)

\begin{tabular}{|c|c|c|c|}
\hline Comparison & Species & Comparison & $\begin{array}{l}\text { Average pairwise } \\
\text { genetic distance }\end{array}$ \\
\hline \multirow[t]{3}{*}{ Northeastern Australia } & O. selheimi & & 0.0054 \\
\hline & N. hyrtlii & & 0.0029 \\
\hline & N. ater & & 0.0013 \\
\hline \multirow[t]{4}{*}{ Gulf of Carpentaria } & O. lineolata & & 0.0013 \\
\hline & O. selheimi & & 0.0037 \\
\hline & N. hyrtlii & & 0.0041 \\
\hline & N. ater & & 0.0013 \\
\hline \multirow[t]{3}{*}{ New Guinea } & O. lineolata & & 0.0041 \\
\hline & O. selheimi & & 0.0006 \\
\hline & N. ater & & 0.0021 \\
\hline \multirow[t]{5}{*}{ Top End } & O. lineolata & & 0.0014 \\
\hline & O. selheimi & & 0.0009 \\
\hline & N. hyrtlii & & 0.0031 \\
\hline & N. ater & & 0.0000 \\
\hline & N. pseudospinosus & & 0.0000 \\
\hline \multirow[t]{6}{*}{ Cambridge Gulf } & O. lineolata & & 0.0008 \\
\hline & O. selheimi & S-A and S-B & 0.0081 \\
\hline & O. selheimi & S-A & 0.0015 \\
\hline & O. selheimi & S-B & 0.0028 \\
\hline & N. hyrtlii & & 0.0040 \\
\hline & N. pseudospinosus & & 0.0008 \\
\hline \multirow[t]{4}{*}{ Kimberley } & O. selheimi & & 0.0109 \\
\hline & N. hyrtlii & & 0.0161 \\
\hline & N. ater & & 0.0000 \\
\hline & N. pseudospinosus & & 0.0000 \\
\hline
\end{tabular}

bridge Gulf samples were not closely related or reciprocally monophyletic, and divergent haplotypes were not restricted to separate catchments (Fig. 2C, Table S1). Oxyeleotris lineolata haplotypes were closely related, but a divergent haplotype (203) occurred in the Ord catchment (Fig. 2C, Table S1).

\section{Kimberley region}

For most species, Kimberly contained highly divergent haplotypes. Neosilurus hyrtlii consisted of 2 haplogroups, $\mathrm{H}-\mathrm{A}$ and H-B (Fig. 2D). Haplotypes in haplogroup H-B were found in the Drysdale and Fitzroy catchments. The haplotypes from H-B found in the Fitzroy catchment were restricted to the Barnett River, Manning Creek, and Hann River (data not shown). These drainages share a headwater drainage divide with the Drysdale catchment, where the rest of the individuals from haplogroup $\mathrm{H}-\mathrm{B}$ were found. Individuals belonging to haplogroup $\mathrm{H}$-A were found throughout the rest of the Fitzroy catchment and in the adjacent May River (Lennard catchment) and Isdell catchment.
Two O. selheimi haplogroups were detected. One (S-B) was restricted to western Kimberley, whereas haplotypes from King Edward and Pentecost belonged to haplogroup S-A (Fig. 2C). One sample of $N$. pseudospinosus from the Fitzroy catchment belonged to a unique haplogroup (P-A) and was $1.2 \%$ divergent from haplogroup P-B (Fig. 2D, Table 2).

\section{DISCUSSION \\ Gulf of Carpentaria}

Consistent with hypothesis 1, all species sampled in Gulf of Carpentaria catchments consisted of closely related haplotypes across the region. This result mirrors those of previous studies in which shallow genetic divergences were found among catchments throughout the gulf region for fishes and crustaceans (de Bruyn et al. 2004, Baker et al. 2008, Masci et al. 2008, Huey et al. 2010, Unmack and Dowling 2010, Cook et al. 2012). These studies clearly show that the large freshwater Lake Carpen- 
taria, which connected rivers across the Gulf of Carpentaria during periods of low sea level, is the primary driver of genetic structure for freshwater organisms in this region (Chivas et al. 2001, Bowman et al. 2010).

Consistent patterns of shallow divergences have been detected for most species in the Gulf of Carpentaria, but investigators have found variation in the timing of connectivity across the region. Dating population divergences among catchments in the gulf has yielded estimates between 25 and 97 thousand years ago (kya) (N. hyrtlii; Huey et al. 2008), 109 and 378 kya (the freshwater fish Ambassis macleayi; Huey et al. 2010), and 130 kya (the freshwater fish Glossamia aprion; Cook et al. 2012). de Bruyn et al. (2004) estimated that populations of the freshwater prawn Macrobrachium rosenbergii in the gulf expanded between 77 and 154 kya. Based on pairwise divergences, Unmack and Dowling (2010) estimated that the most-recent common ancestor (MRCA) of the freshwater fish Craterocephalus stercusmuscarum sampled in the gulf existed $\sim 1.9$ million years ago (mya).

The estimate for C. stercusmuscarum is significantly older than the other estimates, but this difference is at least partly because estimates of MRCA typically are older than estimates of population divergence (such as those presented by Huey et al. 2008, 2010) because the coalescence of genes occurs at some point before the splitting of populations, as a function of effective population size (Hey and Nielsen 2004). Therefore, these estimates may be more concordant than is immediately apparent. Nonetheless, all of these estimates significantly predate the last time the lake was estimated to have been fresh, $\sim 10$ kya (Torgersen et al. 1988, Chivas et al. 2001), and are within the mid- to late-Pleistocene. Cook et al. (2012) suggested that this timing was a result of evaporation of water from catchments before reaching the lake because the region was more arid during the Last Glacial Maximum than at present, so connectivity may have been reduced. Our data support the hypothesis that Lake Carpentaria facilitated widespread connectivity of freshwater taxa in the recent past.

\section{New Guinea}

The Fly River currently drains east of the Torres Strait into the Coral Sea. Some investigators proposed that the Fly River may have flowed west into the Lake of Carpentaria 40 kya (Blake and Ollier 1969, Torgersen et al. 1988), but this hypothesis has been rejected by other authors (Harris et al. 1996). Our results for $N$. ater and O. selheimi support a recent relationship between the Fly River and Gulf catchments. A shared N. ater haplotype probably is the product of incomplete lineage sorting since divergence, rather than recent gene flow. The pattern for $O$. lineolata is more divergent and is suggestive of an older divergence time.
Phylogeographic analysis of the giant freshwater prawn (M. rosenbergii) revealed strong divergence between the Fly River and Gulf of Carpentaria catchments and supported the hypothesis that the Fly River did not flow into the Lake of Carpentaria (de Bruyn et al. 2004). In contrast, Cook and Hughes (2010) found incomplete lineage sorting for Denariusa australis between the eastern gulf catchments and the Fly River, with an estimated divergence of 500 kya. Overall, these results highlight the complex relationship between New Guinea and northern Australia, and suggest that broader sampling across southern New Guinea with additional species is required to help unravel biogeographic patterns.

The overall genetic structure throughout the AMT was lowest in species that also were found in New Guinea. This result suggests that species distribution may be a strong predictor of phylogeographic structure, dispersal ability, and recent range expansions, an observation that also has been made for marine species (Rocha et al. 2007). It seems to be contradicted by the high structuring of the most widely distributed species in our study, N. hyrtlii. However, $N$. hyrtlii may not be a single species and inferences based on its "species" distribution may be misleading.

\section{Northeastern and eastern Australia}

In accordance with hypothesis 2 , species in catchments on either side of Cape York shared a recent common ancestry. The Great Dividing Range creates a drainage divide separating eastern and western drainages on Cape York, but all species sampled on both sides (N. hyrtlii, N. ater, $O$. selheimi, and O. lineolata) exhibited only weak phylogeographic structure across this boundary. Drainage rearrangements (beheading, capture, and diversion; Bishop 1995, Hurwood and Hughes 1998) often have been invoked to explain such patterns, but dispersal across catchment boundaries also can be facilitated by high rainfall in regions of low catchment-boundary relief, a common feature in Australian rivers (Unmack 2013). Of particular relevance for our study is the occurrence of lava flows in the upper Mitchell that may have lowered catchment boundaries and facilitated dispersal across the Great Dividing Range (Unmack 2013).

We sampled 7 distinct drainages for $N$. hyrtlii along the east coast of Australia. This sampling was more thorough than for the other species, and it revealed a large break between the Tully (catchment 36; Fig. 1A) and Muck/Normanby (catchments 34 and 35; Fig. 1A) catchments. The only other species that we sampled as far south on the east coast was $O$. lineolata, and it did not show comparable divergence. Wong et al. (2004) sampled the freshwater fish, Pseudomugil signifer, and detected a similar break that was correlated with the Burdekin Gap, a known biogeographic break in terrestrial organisms. However, the Burdekin Gap is slightly to the south of the Tully catch- 
ment (Fig. 1A). More continuous sampling is required to identify the exact location and possible causes of this divergence.

\section{Gulf of Carpentaria vs the Top End and Cambridge Gulf}

Hypothesis 3 predicted that phylogeographic breaks would be detected west of the Gulf of Carpentaria because catchments across Top End may not have been as connected to Lake Carpentaria and associated drainages as catchments in the Gulf of Carpentaria (Fig. 1A). Divergences were observed between these regions for all species sampled across Top End ( $N$. hyrtlii, $N$. ater, O. selheimi, O. lineolata). However, an O. lineolata haplotype was shared between the regions, and divergences for O. lineolata, $N$. ater, and O. selheimi were low (0.39$1.02 \%)$. These levels of divergence are similar to that observed in a freshwater prawn and a freshwater fish $(0.33$ and $1.3 \%$ respectively; de Bruyn et al. 2004, Huey et al. 2010).

In contrast, $N$. hyrtlii showed a deep divergence (4.8\%), similar to that observed in a freshwater crayfish $(3.9 \%$; Baker et al. 2008). However, for the crayfish, the break was found further east, between the Roper and McArthur catchments (catchments 21 and 22; Fig. 1A). Haplogroups on either side of this region could be separate cryptic species of $N$. hyrtlii, and thus, the intraspecific divergences of $O$. selheimi, O. lineolata, and $N$. ater would not be comparable to the deeper, interspecific divergence found in N. hyrtlii. Future taxonomic research and ecosystem niche modeling may better resolve the biogeographic explanations for this distribution.

\section{Kimberley and Cambridge Gulf}

Hypothesis 5 predicted that Kimberley would harbor many distinct lineages. Kimberley is an ancient landscape, characterized by deep gorges that could have acted as refugia for millions of years (Ollier et al. 1988, Unmack 2001, Gale 2006). In particular, the catchments that drain the sandstone plateau country (Prince Regent, Mitchell, King Edward, and Drysdale) are highly isolated and have high numbers of endemic species and high phylogenetic diversity (Unmack 2001, Cook et al. 2011b, Unmack et al. 2013). In addition, the continental shelf is narrow, which minimizes opportunities for dispersal among drainages during periods of low sea levels (Fig. 1A). Therefore, catchments are likely to remain isolated for long periods of time, leading to divergence and differentiation (e.g., Young et al. 2011). This situation contrasts with that proposed in hypothesis 4, which predicts that catchments to the east of Kimberley (Cambridge Gulf), will show shallow divergences because they all flow onto a broad floodplain, which is expected to facilitate occasional movement across catchment boundaries (Unmack 2001).
Broadly speaking, our results support this description of the region. For the 3 species that were structured across the region ( $N$. hyrtlii, N. pseudospinosus, and O. selheimi), divergent haplogroups with narrow ranges were detected in the Kimberley region ( $\mathrm{H}-\mathrm{A}, \mathrm{H}-\mathrm{B}, \mathrm{P}-\mathrm{A}$, and $\mathrm{S}-\mathrm{B})$ with more widespread clades found in the Carpentaria Gulf region ( $\mathrm{H}-\mathrm{C}, \mathrm{P}-\mathrm{B}$, and $\mathrm{S}-\mathrm{A})$. However, this pattern differed from that of shallowly differentiated $N$. ater, which was sampled in the Fitzroy catchment and was not strongly divergent from the nearest sampled catchment (East Alligator, catchment 18; Fig. 1A).

Within the Cambridge Gulf, most haplotypes were closely related, except for $N$. pseudospinosus and O. selheimi. These species had highly divergent haplotypes in the Daly catchment. The incomplete nature of our sampling design makes discussion of this result challenging. However, multiple clades of Mogurnda mogurnda also have been found in the Daly catchment (Cook et al. 2011a), and the Daly catchment may represent an area of unusually high phylogenetic diversity (Faith 1992).

We sampled 2 divergent haplotypes of $N$. hyrtlii (H-A and $\mathrm{H}-\mathrm{B}, 3.2 \%$ divergent) in western Kimberley (in the Fitzroy catchment, catchment 2; Fig. 1A). However, they were not sympatric. Haplogroup $\mathrm{H}-\mathrm{B}$ was restricted to the Barnett River, Manning Creek, and Hann River, whose headwaters sit adjacent to the Drysdale catchment headwaters. The affinity between these catchments was not detected in the rainbowfish, Melanotaenia australis (Young et al. 2011). Moreover, other authors have suggested that the Fitzroy catchment should share more affinities with the Pentecost and Ord catchments than the Drysdale catchment because the Drysdale catchment drains the sandstone Plateau, is highly isolated, and only shares a short catchment boundary with the Fitzroy catchment (Unmack 2001, Cook et al. 2011b). This unexpected result demonstrates the stochastic nature of intercatchment connectivity for freshwater fish, even in regions with ancient catchments.

\section{Phylogeography and conservation of freshwater species in the AMT}

Our phylogeographic investigation of these 5 species clearly shows that generalizations about intraspecific diversity across the AMT are elusive. Some species had patterns concordant with predicted phylogeographic breaks, but others did not. For example, at 2 extremes, $N$. hyrtlii revealed breaks in the predicted regions, whereas $N$. ater showed a single clade across the entire AMT and New Guinea. These 2 species are similar in their ecology and dispersal behavior (Orr and Milward 1984). Thus, their strikingly different phylogeographic patterns are difficult to explain. Table 3 summarizes genetic information for all freshwater species for which published genetic information from the AMT is available. Patterns range from 


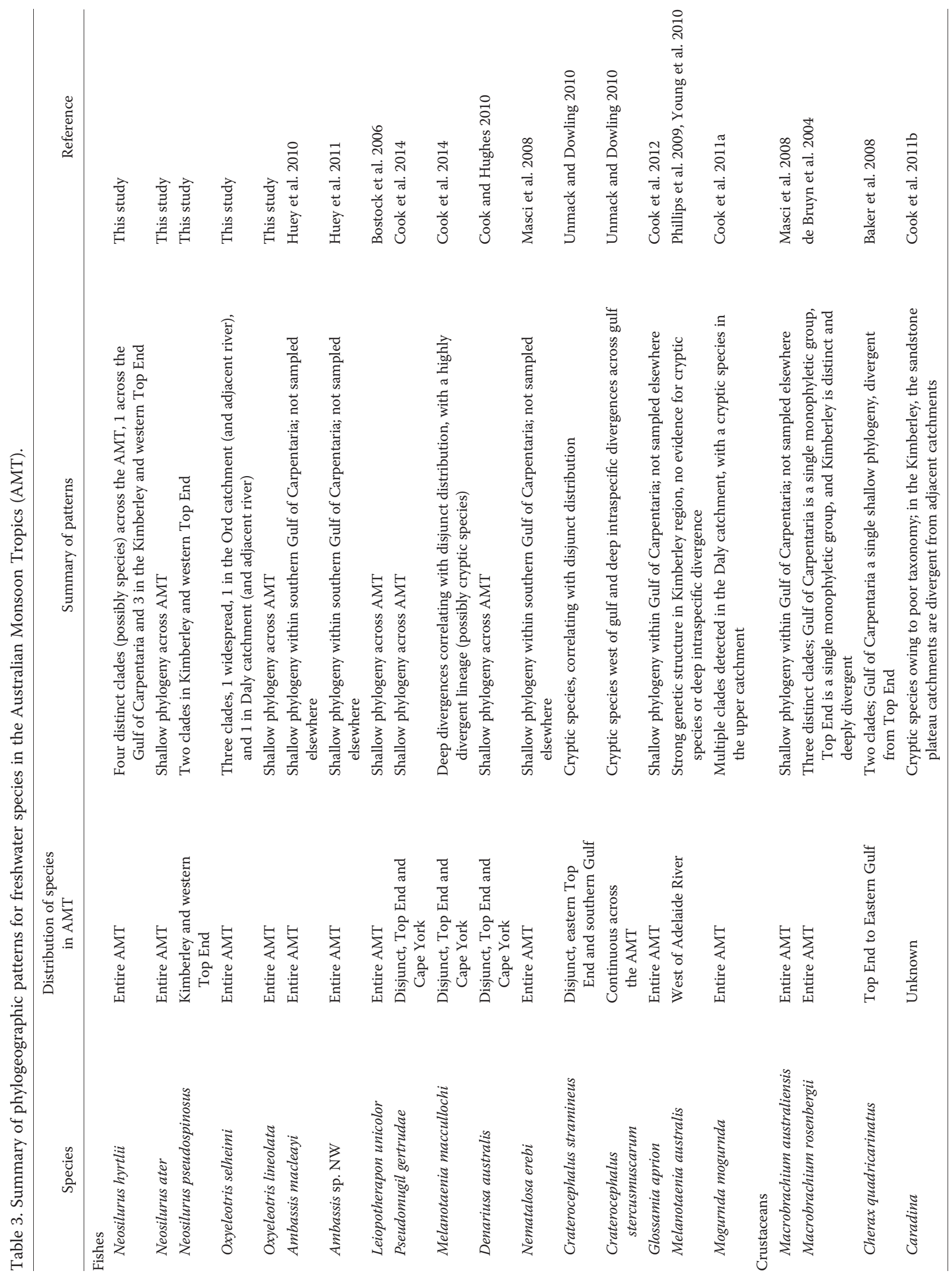


cryptic species and unresolved taxonomy to single unstructured species found across the entire AMT.

The diversity of phylogenetic and phylogeographic patterns described in Table 3 show that more effort is required to describe genetic structure in species across this region and to understand the drivers that shape these patterns. For example, the recent efforts, such as those by Unmack and Dowling (2010) and Unmack et al. (2013), are necessary to identify where current taxonomy is lacking and where research should be focused. Detailed, multilocus studies in which the influence of key biogeographic features on intraspecific diversity is explored, preferably in a statistical phylogeographic framework (Knowles 2009, Hughes et al. 2011), must follow from these initial taxonomic studies. Such studies are lacking for freshwater taxa in the AMT, and future research efforts should focus on these areas.

\section{Management implications for the AMT}

Understanding the full extent of biodiversity is a fundamental question in biology. Therefore, identifying cryptic species and understanding intraspecific diversity, such as Evolutionarily Significant Units (ESUs; Moritz 1994), is necessary to conserve biodiversity (Avise et al. 1987, Bickford et al. 2007). Understanding taxonomic diversity is particularly pertinent in the AMT given the future proposals to develop the region (Bowman et al. 2010).

In preparation for this development, significant effort has gone into preparing systematic conservation plans for freshwater taxa across the AMT and within catchments (Kennard 2010, Hermoso et al. 2012a, b, Linke et al. 2012). The goal of these plans is to identify areas that should be protected to maximize the number of conserved species. All of the plans are based on current understanding of species taxonomy to derive biodiversity surrogates. However, our study shows that significant intraspecific diversity (N. pseudospinosus, O. selheimi) and possibly cryptic species ( $N$. hyrtlii) exist in these 5 species. In addition, other investigators have identified cryptic species and intraspecific variation in other fish in the AMT (Cook and Hughes 2010, Unmack and Dowling 2010, Cook et al. 2011a, 2014, Unmack et al. 2013). Whether this biodiversity is represented in these plans is unknown. Integrating these data into these plans is the next stage in conserving biodiversity in this region. We hope that the patterns described in our study and in Table 3 will prompt more studies of the biodiversity and the mechanisms that have led to its diversification.

\section{ACKNOWLEDGEMENTS}

We acknowledge the Australian Government Department of Sustainability, Environment, Water, Population and Communities, the National Environmental Research Program Northern Australia Hub, the Tropical Rivers and Coastal Knowledge Re- search Hub and the Australian Rivers Institute, Griffith University, for funding this study. Colton Perna, Brad Pusey, Mark Kennard, Damien Burrows, Peter Mather, and Steve Caldwell kindly provided samples. Samples were collected following ethical guidelines (ENV/09/07/AEC) and with appropriate permits (NT permit: COM2003/302:JGS, WA permit: SF006820-201007, QLD permit - PRM03315D and WITK05172208).

\section{LITERATURE CITED}

Allen, G. R., S. H. Midgley, and M. Allen. 2002. Field guide to the freshwater fishes of Australia. Western Australian $\mathrm{Mu}$ seum, Perth, Australia.

Avise, J. C., J. Arnold, R. M. Ball, E. Bermingham, T. Lamb, J. E. Neigel, C. A. Reeb, and N. C. Saunders. 1987. Intraspecific phylogeography: the mitochondrial DNA bridge between population genetics and systematics. Annual Review of Ecology and Systematics 18:489-522.

Baker, N., M. de Bruyn, and P. B. Mather. 2008. Patterns of molecular diversity in wild stocks of the redclaw crayfish (Cherax quadricarinatus) from northern Australia and Papua New Guinea: impacts of Plio-Pleistocene landscape evolution. Freshwater Biology 53:1592-1605.

Bickford, D., D. J. Lohman, N. S. Sodhi, P. K. Ng, R. Meier, K. Winker, K. K. Ingram, and I. Das. 2007. Cryptic species as a window on diversity and conservation. Trends in Ecology and Evolution 22:148-155.

Bishop, P. 1995. Drainage rearrangement by river capture, beheading and diversion. Progress in Physical Geography 19: 449-473.

Blake, D., and C. Ollier. 1969. Geomorphological evidence of Quaternary tectonics in southwestern Papua. Revue de Geomorphologie Dynamique 19:28-32.

$\rightarrow$ Bostock, B., M. Adams, L. Laurenson, and C. Austin. 2006. The molecular systematics of Leiopotherapon unicolor (Günther, 1859): testing for cryptic speciation in Australia's most widespread freshwater fish. Biological Journal of the Linnean Society 87:537-552.

Bowman, D., G. Brown, M. Braby, J. Brown, L. Cook, M. Crisp, F. Ford, S. Haberle, J. Hughes, and Y. Isagi. 2010. Biogeography of the Australian Monsoon Tropics. Journal of Biogeography 37:201-216.

Chivas, A. R., A. García, S. van der Kaars, M. J. J. Couapel, S. Holt, J. M. Reeves, D. J. Wheeler, A. D. Switzer, C. V. Murray-Wallace, and D. Banerjee. 2001. Sea-level and environmental changes since the last interglacial in the Gulf of Carpentaria, Australia: an overview. Quaternary International 83:19-46.

Clement, M., D. Posada, and K. A. Crandall. 2000. TCS: a computer program to estimate gene genealogies. Molecular Ecology 9:1657-1659.

$\rightarrow$ Cook, B. D., M. Adams, P. B. Mather, and J. M. Hughes. 2012. Statistical phylogeographic tests of competing 'Lake Carpentaria hypotheses' in the mouth-brooding freshwater fish, Glossamia aprion (Apogonidae). Marine and Freshwater Research 63:450-456.

Cook, B. D., and J. M. Hughes. 2010. Historical population connectivity and fragmentation in a tropical freshwater fish with a disjunct distribution (Pennyfish, Denariusa bandata). 
Journal of the North American Benthological Society 29: 1119-1131.

Cook, B. D., M. J. Kennard, K. Real, B. J. Pusey, and J. M. Hughes. 2011a. Landscape genetic analysis of the tropical freshwater fish Mogurnda mogurnda (Eleotridae) in a monsoonal river basin: importance of hydrographic factors and population history. Freshwater Biology 56:812-827.

Cook, B. D., T. Page, and J. Hughes. 2011b. Molecular and conservation biogeography of freshwater caridean shrimps in north-western Australia. Pages 273-287 in C. Held, S. Koenemann, and C. D. Schubart (editors). Phylogeography and population genetics in Crustacea. Taylor and Francis Group, Boca Raton, Florida.

Cook, B. D., P. J. Unmack, J. A. Huey, and J. M. Hughes. 2014. Do common disjunct populations of freshwater fishes in northern Australia form from the same biogeographic events? Freshwater Science 33:263-272.

de Bruyn M., J. C. Wilson, and P. B. Mather. 2004. Reconciling geography and genealogy: phylogeography of giant freshwater prawns from the Lake Carpentaria region. Molecular Ecology 13:3515-3526.

Doyle, J. J., and J. L. Doyle. 1987. A rapid DNA isolation procedure for small quantities of fresh leaf tissue. Phytochemistry Bulletin 19:11-15.

Faith, D. P. 1992. Conservation evaluation and phylogenetic diversity. Biological Conservation 61:1-10.

Gale, S. J. 2006. Long-term landscape evolution in Australia. Earth Surface Processes and Landforms 17:323-343.

Harris, P., C. Pattiaratchi, J. Keene, R. Dalrymple, J. Gardner, E. Baker, A. Cole, D. Mitchell, P. Gibbs, and W. Schroeder. 1996. Late Quaternary deltaic and carbonate sedimentation in the Gulf of Papua foreland basin: response to sea-level change. Journal of Sedimentary Research 66:801-819.

Hermoso, V., M. J. Kennard, and S. Linke. 2012a. Integrating multidirectional connectivity requirements in systematic conservation planning for freshwater systems. Diversity and Distributions 18:448-458.

Hermoso, V., M. J. Kennard, B. J. Pusey, and M. Douglas. 2011. Identifying priority areas for the conservation of freshwater biodiversity. Pages 133-149 in B. J. Pusey (editor). Aquatic biodiversity in northern Australia: patterns, threats and future. Charles Darwin University Press, Darwin, Australia.

Hermoso, V., D. P. Ward, and M. J. Kennard. 2012b. Using water residency time to enhance spatio-temporal connectivity for conservation planning in seasonally dynamic freshwater ecosystems. Journal of Applied Ecology 49:1028-1035.

Hey, J., and R. Nielsen. 2004. Multilocus methods for estimating population sizes, migration rates and divergence time, with applications to the divergence of Drosophila pseudoobscura and D. persimilis. Genetics 167:747-760.

Huey, J. A., A. M. Baker, and J. M. Hughes. 2008. The effect of landscape processes upon gene flow and genetic diversity in an Australian freshwater fish, Neosilurus hyrtlii. Freshwater Biology 53:1393-1408.

Huey, J. A., A. M. Baker, and J. M. Hughes. 2010. High levels of genetic structure in the Australian freshwater fish, Ambassis macleayi. Journal of the North American Benthological Society 29:1148-1160.
Huey, J. A., A. M. Baker, and J. M. Hughes. 2011. Evidence for multiple historical colonizations of an endoreic drainage basin by an Australian freshwater fish. Journal of Fish Biology 79:1047-1067.

$\rightarrow$ Huey, J. A., J. M. Hughes, and A. M. Baker. 2006. Patterns of gene flow in two species of eel-tailed catfish, Neosilurus hyrtlii and Porochilus argenteus (Siluriformes: Plotosidae), in western Queensland's dryland rivers. Biological Journal of the Linnean Society 87:457-467.

Hughes, J. M., J. A. Huey, A. J. McLean, and O. Baggiano. 2011. Aquatic insects in eastern Australia: a window on ecology and evolution of dispersal in streams. Insects 2:447-461.

Hughes, J. M., D. J. Schmidt, and D. S. Finn. 2009. Genes in streams: using DNA to understand the movement of freshwater fauna and their riverine habitat. BioScience 59:573583.

Hurwood, D., and J. Hughes. 1998. Phylogeography of the freshwater fish, Mogurnda adspersa, in streams of northeastern Queensland, Australia: evidence for altered drainage patterns. Molecular Ecology 7:1507-1517.

Kennard, M. J. (editor). 2010. Identifying high conservation value aquatic ecosystems in northern Australia. Final report to the Department of Environment, Heritage and the Arts and the National Water Commission. Tropical Rivers and Coastal Knowledge (TRaCK) Commonwealth Environmental Research Facility, Charles Darwin University, Darwin, Australia.

Knowles, L. L. 2009. Statistical phylogeography. Annual Review of Ecology, Evolution, and Systematics 40:593-612.

Linke, S., M. J. Kennard, V. Hermoso, J. D. Olden, J. Stein, and B. J. Pusey. 2012. Merging connectivity rules and large-scale condition assessment improves conservation adequacy in river systems. Journal of Applied Ecology 49:1036-1045.

Masci, K. D., M. Ponniah, and J. M. Hughes. 2008. Patterns of connectivity between the Lake Eyre and Gulf drainages, Australia: a phylogeographic approach. Marine and Freshwater Research 59:751-760.

Michaux, J., R. Libois, and M. Filippucci. 2004. So close and so different: comparative phylogeography of two small mammal species, the Yellow-necked fieldmouse (Apodemus flavicollis) and the Woodmouse (Apodemus sylvaticus) in the Western Palearctic region. Heredity 94:52-63.

Miller, M. A., W. Pfeiffer, and T. Schwartz. 2010. Creating the CIPRES Science Gateway for inference of large phylogenetic trees. Gateway Computing Environments Workshop. IEEE, New York

$\rightarrow$ Moritz, C. 1994. Defining 'evolutionarily significant units' for conservation. Trends in Ecology and Evolution 9:373-374.

Moritz, C., K. S. Richardson, S. Ferrier, G. B. Monteith, J. Stanisic, S. E. Williams, and T. Whiffin. 2001. Biogeographical concordance and efficiency of taxon indicators for establishing conservation priority in a tropical rainforest biota. Proceedings of the Royal Society of London Series B: Biological Sciences 268:1875-1881.

Ollier, C., G. Gaunt, and I. Jurkowski. 1988. The Kimberley Plateau, Western Australia: a Precambrian erosion surface. Zeitschrift für Geomorphologie 32:239-246.

Orr, T., and N. Milward. 1984. Reproduction and development of Neosilurus ater (Perugia) and Neosilurus hyrtlii Steindach- 
ner (Teleostei: Plotosidae) in a tropical Queensland stream. Marine and Freshwater Research 35:187-195.

Phillips, R., A. Storey, and M. Johnson. 2009. Genetic structure of Melanotaenia australis at local and regional scales in the east Kimberley, Western Australia. Journal of Fish Biology 74:437-451.

Pusey, B., M. Kennard, and A. Arthington. 2004. Freshwater fishes of north-eastern Australia. CSIRO Publishing, Collingwood, Australia.

Rocha, L., M. Craig, and B. Bowen. 2007. Phylogeography and the conservation of coral reef fishes. Coral Reefs 26:501512.

Schmidt, D. J., D. A. Crook, J. I. MacDonald, J. A. Huey, B. P. Zampatti, S. Chilcott, T. A. Raadik, and J. M. Hughes. 2014. Migration history and stock structure of two putatively diadromous teleost fishes, as determined by genetic and otolith chemistry analyses. Freshwater Science 33:193-206.

$\rightarrow$ Stamatakis, A. 2006. RAxML-VI-HPC: maximum likelihoodbased phylogenetic analyses with thousands of taxa and mixed models. Bioinformatics 22:2688-2690.

Stamatakis, A., P. Hoover, and J. Rougemont. 2008. A rapid bootstrap algorithm for the RAxML Web servers. Systematic Biology 57:758-771.

Tamura, K., D. Peterson, N. Peterson, G. Stecher, M. Nei, and S. Kumar. 2011. MEGA5: molecular evolutionary genetics analysis using maximum likelihood, evolutionary distance, and maximum parsimony methods. Molecular Biology and Evolution 28:2731-2739.
Torgersen, T., J. Luly, P. de Deckker, M. Jones, D. Searle, A. Chivas, and W. Ullman. 1988. Late Quaternary environments of the Carpentaria Basin, Australia. Palaeogeography, Palaeoclimatology, Palaeoecology 67:245-261.

Unmack, P. J. 2001. Biogeography of Australian freshwater fishes. Journal of Biogeography 28:1053-1089.

Unmack, P. J. 2013. Biogeography. in P. Humphries and K. Walker (editors). Ecology of Australian freshwater fishes. CSIRO Publishing, Collingwood, Victoria (in press).

Unmack, P. J., G. R. Allen, and J. B. Johnson. 2013. Phylogeny and biogeography of rainbowfishes (Melanotaeniidae) from Australia and New Guinea. Molecular Phylogenetics and Evolution 67:15-27.

Unmack, P. J., and T. E. Dowling. 2010. Biogeography of the genus Craterocephalus (Teleostei: Atherinidae) in Australia. Molecular Phylogenetics and Evolution 55:968-984.

Voris, H. K. 2001. Maps of Pleistocene sea levels in Southeast Asia: shorelines, river systems and time durations. Journal of Biogeography 27:1153-1167.

Wong, B., J. Keogh, and D. McGlashan. 2004. Current and historical patterns of drainage connectivity in eastern Australia inferred from population genetic structuring in a widespread freshwater fish Pseudomugil signifer (Pseudomugilidae). Molecular Ecology 13:391-401.

Young, M. J., J. P. Evans, and L. W. Simmons. 2011. Population genetic structure and a possible role for selection in driving phenotypic divergence in a rainbowfish (Melanotaeniidae). Biological Journal of the Linnean Society 102:144-160. 